\title{
Genetic, Ethnic, and Gender Differences in the Pharmacokinetics of Antiretroviral Agents
}

\author{
Margalida Rotger, PharmD, Chantal Csajka, PharmD, PhD, \\ and Amalio Telenti, $M D, P h D$
}

\author{
Corresponding author \\ Amalio Telenti, MD, PhD \\ Institute of Microbiology and University Hospital, \\ Lausanne, Switzerland. \\ E-mail: amalio.telenti@chuv.ch
}

Current HIV/AIDS Reports 2006, 3:118-125

Current Science Inc. ISSN 1548-3568

Copyright (C) 2006 by Current Science Inc.

Variable antiretroviral therapy (ART) drug response likely reflects the combined influence of environment, underlying disease, concurrent drugs, and genetics. Gender exerts modest or negligible effects on ART disposition, and it is expected to have limited clinical implication, although it should be accounted for in large population studies. Ethnic denominations have, with the notable exception of efavirenz, no clear influence on ART disposition. Exploration of genetic factors might offer a better comprehension to the largely unpredictable and unresolved variability in ART concentrations and related toxicity or treatment outcome. Despite the negative perception of genetic research among the general public, this type of investigation is now widely accepted by concerned parties: patients, relatives, and study volunteers.

\section{Introduction}

There is marked interindividual variation in plasma levels, efficacy, and in susceptibility to adverse effects of antiretroviral therapy (ART). Variable drug response may reflect the combined influence of exogenous factors (environment, underlying disease, concurrent drugs), as well as gender, ethnicity, and genetics. In this regard, variation in the genes that encode for proteins involved in the metabolism or disposition of ART is thought to represent a key determinant of their efficacy and toxicity. Genetic variation also underlies differences in treatment response that are ascribed to ethnicity. In this update, we describe advances in the understanding of pharmacogenetic factors relevant to ART, as well as gender and ethnic determi- nants of response. Finally, we will comment on specific research initiatives aiming at bringing genetic prediction to clinical use.

\section{Gender and Pharmacokinetics}

Sex or other sex-specific factors can influence ART pharmacokinetic profile, the incidence of adverse reactions, and

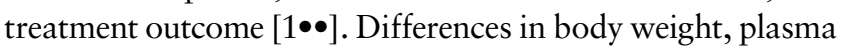
volume, gastric emptying time, plasma protein levels, hepatic enzyme expression and activity, drug transporters function, excretion activity, or sex-specific conditions (pregnancy, hormonal therapy) may account for the gender variation in drug

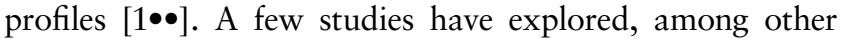
covariates, the influence of sex on the disposition parameters of ART in order to explain the large interpatient variability in the kinetic profile of these agents. Investigations of a sex-based effect on the pharmacokinetics of antiretroviral agents have provided inconsistent results between studies and among certain agents. These results are summarized in Table 1. A significant sex-effect was reported for indinavir in three population studies, which reported a decrease in apparent clearance in female compared with male patients after adjustment for body weight $[2,3]$, as well as an increase in indinavir bioavailability in women [4]. Other investigators observed roughly similar pharmacokinetic parameters in women than in men [5]. In studies on saquinavir alone and saquinavir boosted by ritonavir, female patients had higher exposure, maximal, and trough concentrations of saquinavir and ritonavir [6,7] as well as a $50 \%$ reduction of clearance compared with male patients, after adjustment for body weight [8]. In contrast, no sex-related differences were reported in lopinavir [6,9], nelfinavir [10], amprenavir [11], and atazanavir (unpublished data) pharmacokinetic profiles.

Studies on the non-nucleoside reverse transcriptase inhibitors are not fully conclusive. Efavirenz was not shown to be influenced by sex in three studies $[12,13 \bullet, 14]$, whereas one investigation reported a small decrease in apparent clearance [15] and others reported a sustained increase in mean efavirenz concentrations in female compared with male patients $[16,17]$. No sex-related difference 
in nevirapine elimination was reported by some authors $[18,19]$, whereas two studies revealed a decrease in nevirapine clearance in females $[14,20]$.

The nucleoside reverse transcriptase inhibitors didanosine, tenofovir, lamivudine, and zidovudine pharmacokinetic profiles were not found to be influenced by gender $[18,20$ 22]. Interestingly, median intracellular concentrations of zidovudine triphosphate and lamivudine triphosphate were markedly increased in women compared with men without any other biologic explanation [21]. Finally, in the HIV-1 fusion inhibitor enfuvirtide, elimination was reported to be reduced in female compared with male patients [23].

Taken as a whole, these results suggest that, although of moderate clinical implication, the sex-based differences on the plasma and intracellular levels of antiretroviral agents should be accounted for in large population studies, in particular in the view of concomitant impacting factors such as other demographic covariates, comedications, or underlying diseases, ethnicity, and genetic differences. Additional data can be found in the registration files of the various drugs.

\section{Ethnicity-related Differences in Pharmacokinetics}

Geographic patterns of genetic variation indicate that geographic structuring of interindividual variation in drug concentration and response may occur $[24 \bullet \bullet]$. This is the basis for investigating whether ethnic, racial, or ancestry factors influence ART. Unfortunately, most of the available studies rarely include more than $25 \%$ of non-whites in the analysis. A better representation of the various ethnic groups is clearly needed (Table 1 ).

Several studies on efavirenz have revealed ethnic-related differences in the clearance or bioavailability and of the plasma concentrations of this drug. A population metaanalysis of 16 phase I studies revealed a decrease in efavirenz apparent clearance in blacks and Asians compared with that of whites [15]. Two subsequent population analyses of efavirenz in a cohort of 235 [12] and 398 [13•] individuals with HIV infection showed a modest but significant increase in bioavailability and a decrease in apparent clearance in the black and Hispanic subpopulations versus whites. Similarly, a clear increase in bioavailability in Asians versus whites with no effect on clearance or volume of distribution was reported in a cohort of 178 patients [25]. Blacks and Hispanics were reported to present double maximal concentrations and drug exposure compared with whites in a cohort of 190 patients as well [26•] and similar increases in mean efavirenz plasma concentrations were observed in blacks and in Asians [16]. An important genetic component to these ethnic differences is discussed below. A few analyses of nevirapine kinetics did not report any ethnic differences in elimination $[18,20]$.

Several population pharmacokinetic studies have investigated the influence of ethnicity to explain the large interindividual variability in the plasma levels of protease inhibitors. No ethnicity-based difference in the pharmacokinetic parameters of indinavir [3,4], nelfinavir [10], saquinavir [8], lopinavir [9], and atazanavir (unpublished data) are reported. A study on amprenavir did not report any influence of ethnicity on its elimination [11]. Another cross-study analysis of three single-dose studies in 83 HIVpositive and -negative individuals explored the relationship between amprenavir, $\alpha 1$-glycoprotein (AAG) level in plasma and ethnicity [27]. The authors found that mean concentrations of AAG were $17 \%$ lower in black individuals compared with whites and that a significant inverse linear relationship was found between AAG concentration and amprenavir apparent clearance. The observed differences in amprenavir elimination might partially reflect a contribution of ethnicity-associated genotypic-differences in AAG concentrations $[28,29]$. The same relationship between ethnicity, AAG concentrations and clearance are also observed for indinavir and lopinavir (unpublished data). No differences in zidovudine and lamivudine kinetics were observed between whites and other populations [21].

Thus, except for efavirenz, no clear influence of an ethnic component on ART disposition has been evidenced. It has been suggested that the commonly used ethnic labels might be insufficient and inaccurate representations of actual genetic clusters and that the drug-metabolizing profiles differ significantly among the different clusters [24••]. Exploration of genetic-related factors might offer a better comprehension to the largely unpredictable and unresolved variability in antiretroviral agents' concentrations and related toxicity or treatment outcome. However, Ioannidis et al. [30] emphasized that although allelic frequency may vary across ethnic groups, the specific effect of a functional variant allele was conserved.

\section{Genetic Variation in Genes Involved in the Pharmacokinetics of Antiretroviral Agents Genetic variation in drug-metabolizing enzymes}

Drug metabolism can be divided in two phases: phase I, that may occur by oxidation, reduction or hydrolysis, and phase II, where drugs are conjugated with polar-endogenous compounds that will facilitate their elimination from the body. Cytochrome (CYP) P450 is a group of hemecontaining enzymes responsible for the majority of phase I metabolism. Five CYP enzymes (CYP3A4, CYP3A5, CYP2C19, CYP2D6, and CYP2B6) are involved in the metabolism of ART. Genetic polymorphism may result in poor metabolizer phenotype due to gene deletion, to mutations creating an alternative splice site, or a premature stop codon that results in nonexpressed, nonfunctional truncated proteins. At the other side of the spectrum, there are individuals presenting ultra-rapid metabolizer phenotypes due to a phenomenon of gene duplication. A significant number of nonsynonymous (amino acid-changing) variants alter enzyme function. The frequency of these genetics variants differs among ethnic groups [24••] (Table 2). 


\begin{tabular}{|c|c|c|c|c|c|}
\hline $\begin{array}{l}\text { Drug } \\
\text { Pls }\end{array}$ & Gender (women vs men) & Study & \multicolumn{2}{|c|}{ Ethnicity (\% of patients in each ethnic group) } & \multirow[t]{2}{*}{ Study } \\
\hline & & & & & \\
\hline \multirow[t]{2}{*}{ Lopinavir } & $\begin{array}{l}\text { No difference in } \mathrm{CL}, \mathrm{AUC} \text {, } \\
\mathrm{C}_{\max } \text { and } \mathrm{C}_{\text {trough }}\end{array}$ & {$[6,9]$} & $\begin{array}{l}\text { White (75) } \\
\text { Black (14) } \\
\text { Asian (9) }\end{array}$ & No difference in $\mathrm{CL}$ & [9] \\
\hline & & & $\begin{array}{l}\text { White (90) } \\
\text { Black (6) } \\
\text { Asian (9) } \\
\text { Hispanic (8) }\end{array}$ & $\begin{array}{c}\text { Lower mean AAG in black, Asian, } \\
\text { and Hispanic. Inverse relationship } \\
\text { between AAG and CL }\end{array}$ & UD \\
\hline \multirow[t]{3}{*}{ Indinavir } & $\begin{array}{l}\text { Decrease in } \mathrm{CL} \\
\text { Increase in } \mathrm{F}\end{array}$ & {$[2-4]$} & $\begin{array}{l}\text { White (82-92) } \\
\text { Black (5-9) } \\
\text { Asian (1-5) }\end{array}$ & No difference in $\mathrm{CL}$ & {$[3,4]$} \\
\hline & Lower $\mathrm{C}_{\min }$ & & $\begin{array}{l}\text { White (90) } \\
\text { Black (6) } \\
\text { Asian (9) } \\
\text { Hispanic (8) }\end{array}$ & $\begin{array}{c}\text { Lower mean AAG in black, Asian, } \\
\text { and Hispanic. Inverse relationship } \\
\text { between AAG and CL }\end{array}$ & UD \\
\hline & No difference in concentrations & [5] & & & \\
\hline Nelfinavir & No difference in $\mathrm{CL}$ & {$[10]$} & $\begin{array}{l}\text { White (78) } \\
\text { Black (12) } \\
\text { Asian (2) }\end{array}$ & No difference in $\mathrm{CL}$ & {$[10]$} \\
\hline \multirow[t]{2}{*}{ Amprenavir } & No difference in $\mathrm{CL}, \mathrm{V}$ & [11] & $\begin{array}{l}\text { White (66) } \\
\text { Other (34) }\end{array}$ & No difference in $C L, V$ & {$[11]$} \\
\hline & & & $\begin{array}{l}\text { White (59) } \\
\text { Black (40) }\end{array}$ & $\begin{array}{l}\text { Lower mean AAG in black. Inverse } \\
\text { relationship between AAG and CL }\end{array}$ & [27] \\
\hline Saquinavir & $\begin{array}{l}\text { Decrease in } \mathrm{CL} \text {, higher } \mathrm{AUC} \text {, } \\
\mathrm{C}_{\text {max }^{\prime}} \text { and } \mathrm{C}_{\text {trough }}\end{array}$ & {$[6-8]$} & $\begin{array}{l}\text { White (52) } \\
\text { Black (27) } \\
\text { Hispanic (17) } \\
\text { Asian (2) }\end{array}$ & No difference in $\mathrm{CL}$ & {$[8]$} \\
\hline Ritonavir & $\begin{array}{l}\text { Decrease in } \mathrm{CL} \text {, higher } \mathrm{AUC} \text {, } \\
\mathrm{C}_{\text {max }^{\prime}} \text { and } \mathrm{C}_{\text {trough }}\end{array}$ & {$[6,7]$} & & & \\
\hline Atazanavir & No difference $C L$ & UD & $\begin{array}{l}\text { White (86) } \\
\text { African (9) } \\
\text { Asian (3) }\end{array}$ & No difference in $\mathrm{CL}$ & UD \\
\hline
\end{tabular}

AAG— $\alpha 1$-glycoprotein; AUC — area under the concentration-time curve; $\mathrm{C}_{\mathrm{av}}$-average concentration; $\mathrm{CL}$-clearance; $\mathrm{C}_{\text {max }}$-maximal concentration; $\mathrm{C}_{\min }$ - minimal concentration; $\mathrm{C}_{\mathrm{ss}}$ - concentration at steady-state; $\mathrm{C}_{\text {trough }}$ - trough concentration; $\mathrm{F}$-bioavailability; NNRTI-non-nucleoside reverse transcriptase inhibitor; $\mathrm{NRTI}$-nucleoside transcriptase inhibitor; Pl — protease inhibitor; UD—unpublished data; $\mathrm{V}$-volume of distribution.

CYP3A4 and CYP3A5 are responsible for the metabolism of $50 \%$ of therapeutic drugs. Both are polymorphic: 20 different alleles are described for CYP3A4 and 11 for CYP3A5 (Table 2). Studies performed to evaluate the effect of CYP $3 A 4 * 1 B, C Y P 3 A 5 * 3$, and CYP $3 A 5 * 6$ on the pharmacokinetics of nelfinavir $[31 \bullet \bullet, 32 \bullet \bullet]$, efavirenz $[26 \bullet, 31 \bullet \bullet, 32 \bullet \bullet]$, and saquinavir $[33,34]$ indicate no influence on nelfinavir and efavirenz pharmacokinetics. In contrast, CYP3A $5 * 3$ has been associated with the urinary metabolic ratio of saquinavir to its hydroxy metabolites in healthy individuals [33,34]. Differences in levels of CYP3A expression appear more relevant to ART metabolism than specific genetic variants [35].

CYP2D6 is the most polymorphic of all CYP enzymes with 58 alleles described (Table 2). A study published

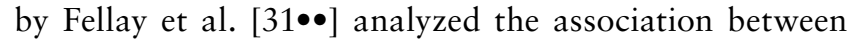
CYP2D6 genetic variations and plasma levels of nelfinavir and efavirenz in treatment-naïve individuals with
HIV infection. Individuals homozygous or heterozygous for a loss-of-function CYP2D6 allele had higher median plasma concentrations of both drugs. However, CYP2D6 is not thought to participate significantly to the metabolism of these drugs, and the results await confirmation.

There are 21 different alleles described for CYP2C19. A recent study demonstrated that nelfinavir exposure was significantly higher in treatment-naïve individuals with GA or AA genotypes at position 681 in CYP2C19 (ie, CYP2C19*2) compared with the common allele. The same study showed a trend toward decreased virologic failure in individuals with the GA genotype. Genotypic differences are also observed among ethnic groups because $2 \%$ to $3 \%$ of whites and $4 \%$ of blacks have the poor metabolizer phenotype versus $10 \%$ to $25 \%$ of Asians [36].

CYP2B6 is also polymorphic (21 alleles described) particularly in blacks. Different studies have shown that $516 \mathrm{G}>\mathrm{T}$ single nucleotide polymorphism (SNP) in exon 


\begin{tabular}{|c|c|c|c|c|c|}
\hline Drug & Gender (women vs men) & Study & Ethnicity (\% & of patients in each ethnic group) & Study \\
\hline \multicolumn{6}{|l|}{ NNRTI } \\
\hline \multirow[t]{2}{*}{ Efavirenz } & No difference in $\mathrm{CL}, \mathrm{V}, \mathrm{F}$ & {$[12,13 \bullet, 14]$} & $\begin{array}{l}\text { White }(57-82) \\
\text { Black (16-32) } \\
\text { Hispanic }(5-11) \\
\text { Asian (2) }\end{array}$ & $\begin{array}{l}\text { AUC, } C_{\max } \text { and } C_{\text {av }} \text { greater in black, } \\
\text { Hispanic, and Asian. Decrease in } \\
C L, F \text { in black and Asian. }\end{array}$ & $\begin{array}{c}{[12,13 \bullet, 15,} \\
16,26 \bullet]\end{array}$ \\
\hline & Decrease in $C L$, increase in $C_{a v}$ & {$[15-17]$} & $\begin{array}{l}\text { White (75) } \\
\text { Black (15) } \\
\text { Asian (7) } \\
\text { Hispanic (4) }\end{array}$ & $\begin{array}{l}\text { Increase in } F \text { in Asian. } \\
\text { No difference in } C L, V\end{array}$ & [25] \\
\hline \multirow[t]{2}{*}{ Nevirapine } & No difference in $\mathrm{CL}$ and $\mathrm{V}$ & {$[18,19]$} & $\begin{array}{l}\text { White (82-89) } \\
\text { Black (6-19) } \\
\text { Hispanic (10) }\end{array}$ & No difference in $\mathrm{CL}, \mathrm{V}$ & {$[18,20]$} \\
\hline & Decrease in $\mathrm{CL}$ & [14] & Asian (2-3) & & \\
\hline \multicolumn{6}{|l|}{ NRTI } \\
\hline Tenofovir & No difference in $\mathrm{CL}$ & [22] & & & \\
\hline Didanosine & No difference in $\mathrm{CL}, \mathrm{V}, \mathrm{F}$ & [20] & $\begin{array}{l}\text { White (81) } \\
\text { Black (9) } \\
\text { Hispanic (10) }\end{array}$ & No difference in $C L, V, F$ & {$[20,25]$} \\
\hline Lamivudine & No difference in $\mathrm{CL}$, plasma $\mathrm{C}_{\mathrm{ss}}$ & {$[18,21]$} & $\begin{array}{l}\text { White (70) } \\
\text { Black (21) }\end{array}$ & No difference in $\mathrm{CL}$ & [21] \\
\hline $\begin{array}{l}\text { Lamivudine } \\
\text { triphosphate }\end{array}$ & $\begin{array}{l}\text { Higher median intracellular } \\
\text { concentration }\end{array}$ & [21] & & & \\
\hline Zidovudine & No difference in $\mathrm{CL}, \mathrm{V}, \mathrm{F}, \mathrm{C}_{\mathrm{ss}}$ & [21] & $\begin{array}{l}\text { White (70) } \\
\text { Black (21) }\end{array}$ & No difference in $\mathrm{CL}$ & [21] \\
\hline $\begin{array}{l}\text { Zidovudine } \\
\text { triphosphate }\end{array}$ & $\begin{array}{l}\text { Higher median intracellular } \\
\text { concentration }\end{array}$ & [21] & & & \\
\hline \multicolumn{6}{|c|}{ Fusion inhibitor } \\
\hline Enfuvirtide & Decrease in $\mathrm{CL}$ & [23] & & & \\
\hline
\end{tabular}

4 (marker for CYP2B6*6 with a high allelic frequency in blacks) is significantly associated with high plasma levels of non-nucleoside reverse transcriptase inhibitors (efavirenz and nevirapine) $[26,37,38 \bullet, 39 \bullet]$. In addition, the 983T>C SNP in exon 7 (marker for CYP2B6*16 and *18 [only found among blacks]) has also been associated with high efavirenz plasma levels $[40 \bullet \bullet, 41]$. Efavirenz concentrations are more profoundly altered in individuals carrying two copies of loss-of-function alleles: generally one copy of CYP2B6*6 with a second copy including alleles "11 and *18 or new alleles, such as M198T and R378stop [42].

\section{Genetic variation in drug transporters}

Drug transporters play also an important role in the disposition of ART. There are two major types: uptake and efflux transporters. P-glycoprotein, the gene product of $A B C B 1 / M D R 1$, an efflux transporter, has received the greatest attention in terms of identification of genetics variants. Protease inhibitors are substrates of this transporter.
Screening of the entire $A B C B 1$ coding region identified a synonymous SNP in exon 26 (ie, 3435C $>\mathrm{T}$ ) possibly associated with altered protein expression and mRNA stability, although the particular SNP does not change the encoded amino acid (isoleucine) $[43,44]$. The allelic frequency of this SNP also differs among ethnic groups being more common in whites and Asians $(\sim 0.5)$ than in blacks (0.10) [45]. Different studies attempting to define associations between this SNP and other ABCB1 variants, and the pharmacokinetics of several protease inhibitors and efavirenz have resulted in conflicting and controversial findings $[31 \bullet \bullet, 32 \bullet \bullet, 46 \bullet]$.

The members of the multidrug resistance-associated (MRP) protein family are efflux transporters that have the potential to affect the disposition of ART. Colombo et al. [46•] evaluated the effect of different genetic variants in $A B C C 1$ and $A B C C 2$ (the genes coding for MRP1 and MRP2) on cellular levels of nelfinavir indicating no influence of these variants. MRP4 and MRP5 are involved in the transport of adefovir and different 
Table 2. Frequency of functionally relevant alleles and ethnic differences for selected metabolizing enzyme, transporter, and nuclear receptor alleles

\begin{tabular}{|c|c|c|c|c|}
\hline Gene* $^{*}$ & $\begin{array}{l}\text { Alleles with altered } \\
\text { function (total no. } \\
\text { of known alleles) }\end{array}$ & $\begin{array}{l}\text { Ethnicity differences } \\
\text { in frequency of } \\
\text { altered functional } \\
\text { alleles ( } \geq 1.5 \text {-fold) }\end{array}$ & $\begin{array}{l}\text { Altered function alleles } \\
\text { only described in one } \\
\text { ethnic group }\end{array}$ & Effect on ART \\
\hline СУРЗА4 & $11(20)$ & $* 1 B, * 11$ & $\begin{array}{c}\mathrm{W}: * 2, * 8, * 12, * 13, * 17 \\
\mathrm{~A}: * 4, * 5, * 6, * 18\end{array}$ & $\begin{array}{c}\text { Studied in EFV and NFV. } \\
\text { Possible effect of *1B on } \\
\text { EFV plasma AUC. }\end{array}$ \\
\hline CYP3A5 & $6(11)$ & $* 3, * 6$ & $\begin{array}{c}\mathrm{W}: * 10 \\
\mathrm{~B}: * 7, * 8 \\
\mathrm{~A}: * 9\end{array}$ & $\begin{array}{c}\text { Studied in EFV, NFV, and SQV. } \\
\text { Possible effect of *3 on EFV } \\
\text { plasma AUC. Relevance } \\
\text { of } 3 \text { on SQV metabolism. }\end{array}$ \\
\hline CYP2D6 & $29(58)$ & $\begin{array}{c}* 2 x n, * 3, * 4, * 6, * 9 \\
* 10, * 12, * 17, * 29 \\
* 35, * 36\end{array}$ & $\begin{array}{c}\mathrm{W}: * 7, * 8, * 11, * 13, * 15 \\
* 16, * 19, * 20, * 31 \\
\mathrm{~B}: * 40, * 42 \\
\mathrm{~A}: * 14, * 18, * 21, * 44\end{array}$ & $\begin{array}{l}\text { Studied in EFV and NFV. } \\
\text { Controversial relevance. }\end{array}$ \\
\hline CYP2C19 & $11(21)$ & $* 2, * 3, * 4, * 17$ & $\begin{array}{c}\mathrm{W}: * 6, * 7, * 8 \\
\mathrm{~B}: * 9, * 10, * 12 \\
\mathrm{~A}: * 5\end{array}$ & $\begin{array}{c}\text { Studied in EFV and NFV. } \\
\text { Possible effect of } * 2 \text { on } \\
\text { NFV plasma AUC. }\end{array}$ \\
\hline CYP2B6 & $14(25)$ & $* 5, * 6, * 7, * 22$ & $\begin{array}{l}\mathrm{W}: * 8, * 11, * 12, * 14, * 15 \\
\mathrm{~B}: * 16, * 18, * 19, * 20, * 21\end{array}$ & $\begin{array}{l}\text { Studied in NFV, EFV, } \\
\text { and NVP. Influences EFV } \\
\text { and NVP plasma and } \\
\text { intracellular AUC. }\end{array}$ \\
\hline$A B C B 1^{+}$ & $\begin{array}{c}\text { 3435C }>\mathrm{T} \text { (in linkage } \\
\text { disequilibrium with 1236C }>\mathrm{T} \text {, } \\
2677 \mathrm{G}>\mathrm{T} \text { and IVS26+80T }>C \text { ) }\end{array}$ & $\begin{array}{c}\text { Allelic frequency of } \\
3435 \text { T higher in } \\
\text { whites and Asians } \\
\text { than in blacks }\end{array}$ & - & $\begin{array}{r}\text { Studied in EFV, NFV, LPV, RTV, } \\
\text { and IDV. Controversial effect }\end{array}$ \\
\hline$P X R$ & $3(8)$ & $* 3$ & $\begin{array}{l}\mathrm{W}: * 4 \\
\mathrm{~B}: * 2\end{array}$ & None reported \\
\hline$C A R$ & $\begin{array}{l}\text { Different single nucleotide poly- } \\
\text { morphisms described but no } \\
\text { allele assignment (unknown } \\
\text { impact on function) }\end{array}$ & - & $\begin{array}{l}\text { Only in Asians (unknown } \\
\text { impact on function) }\end{array}$ & None reported \\
\hline
\end{tabular}

nucleoside reverse transcriptase inhibitors, such as azidothymidine, lamivudine, zalcitabine, and stavudine [47]. Numerous genetics variants have been identified for $A B C C 4$ and $A B C C 5$ (the genes coding for MRP4 and MRP5, respectively) [48], although their effect on ART is yet to be evaluated.

\section{Regulation of drug-metabolizing enzymes and drug transporters}

CYP enzymes and drug transporters present wide interindividual variability in expression and function that cannot be completely explained by drug interactions and/or genetic variation, suggesting that transcriptional regulators may contribute to these differences. Pregnane $\mathrm{X}$ receptor (PXR) and constitutive androstane receptor (CAR) are members of the nuclear receptor superfam- ily that, once activated by ligands, can regulate the transcription of different target genes [49]. Genetic polymorphisms have been described for $P X R$ and $C A R$ present at low allelic frequency $(\leq 3 \%)$ in the general population except for P27S $(79 \mathrm{C}>\mathrm{T})(P X R * 2)$ that is highly frequent in blacks $(0.22)$ [50,51]. Their effect on ART is yet to be evaluated.

\section{Genetic variations in AAG}

AAG, also called orosomucoid (ORM), is a small acute-phase glycoprotein that extensively binds the protease inhibitors. Protein-binding may affect ART activity by decreasing the amount of free drug capable to exert an effect. Two proteins (ORM1 and ORM2) encoded by two functional genes (ORM1 and ORM2) exist. AAG concentration is higher in whites than in 
blacks or Asians [28,29]. ORM2 is monomorphic in most populations whereas ORM1 is polymorphic with three alleles described: ORM1*F1, ORM1*F2, and ORM1*S. ORM1*F1 and *S are observed worldwide, whereas $* F 2$ is rare. The influence of ORM concentrations as well as genetic variants in the pharmacokinetics of ART has been recently evaluated by Colombo et al. [52]. ORM concentrations influenced indinavir apparent clearance $\left(\mathrm{CL}_{\text {app }}\right)$ and to a less extent lopinavir $\mathrm{CL}_{\text {app }}$. Indinavir $\mathrm{CL}_{\text {app }}$ was significantly higher in individuals $* F 1 * F 1$ and ${ }^{*} F 1 * S$ than $* S * S$.

\section{Conclusions}

The number of genetic association studies is growing rapidly. A number of recommendations for optimal design of genetic association studies and for conducting of clinical trials and for cohort studies are presented elsewhere [53]. Evaluation and integration of genetic data for clinical use will be facilitated by initiatives such as the Adult AIDS Clinical Trials Group Protocol A5128 [54••], and the GENOMICS protocol ("Collection and use of blood for genetic and other related analyses") sponsored by the National Institutes for Allergy and Infectious Disease. Both protocols establish the conditions to storing DNA for studies that were not planned when informed consent was provided, and for future analyses. The GENOMICS protocol aims at providing genetic data to the Community Programs for Clinical Research on AIDS, with a particular interest in people of color, women, and injection drug users. Despite the negative perception of genetic research among the general public, recent studies indicate that this type of investigation is widely accepted by concerned parties: patients, relatives, and healthy study volunteers $[55 \bullet \bullet]$.

\section{References and Recommended Reading}

Papers of particular interest, published recently, have been highlighted as:

- Of importance

- Of major importance

1.•• Gandhi M, Aweeka F, Greenblatt RM, Blaschke TF: Sex differences in pharmacokinetics and pharmacodynamics. Annu Rev Pharmacol Toxicol 2004, 44:499-523.

This review examines the biologic bases of differences in pharmacokinetics and pharmacodynamics between genders.

2. Brendel K, Legrand M, Taburet AM, et al.: Population pharmacokinetic analysis of indinavir in HIV-infected patient treated with a stable antiretroviral therapy. Fundam Clin Pharmacol 2005, 19:373-383.

3. Csajka C, Marzolini C, Fattinger K, et al.: Population pharmacokinetics of indinavir in patients infected with human immunodeficiency virus. Antimicrob Agents Chemother 2004, 48:3226-3232.

4. Kappelhoff BS, Huitema AD, Sankatsing SU, et al.: Population pharmacokinetics of indinavir alone and in combination with ritonavir in HIV-1-infected patients. Br J Clin Pharmacol 2005, 60:276-286.
5. Burger DM, Siebers MC, Hugen PWH, et al.: Pharmacokinetic variability caused by gender: do women have higher indinavir exposure than in men? J Acquir Immune Defic Syndr 2002, 29:101-102.

6. Ribera E, Lopez RM, Diaz M, et al.: Steady-state pharmacokinetics of a double-boosting regimen of saquinavir soft gel plus lopinavir plus minidose ritonavir in human immunodeficiency virus-infected adults. Antimicrob Agents Chemother 2004, 48:4256-4262.

7. Pai MP, Schriever CA, az-Linares M, et al.: Sex-related differences in the pharmacokinetics of once-daily saquinavir soft-gelatin capsules boosted with low-dose ritonavir in patients infected with human immunodeficiency virus type 1 . Pharmacotherapy 2004, 24:592-599.

8. Fletcher CV, Jiang H, Brundage RC, et al.: Sex-based differences in saquinavir pharmacology and virologic response in AIDS Clinical Trials Group Study 359. J Infect Dis 2004, 189:1176-1184.

9. Crommentuyn KM, Kappelhoff BS, Mulder JW, et al.: Population pharmacokinetics of lopinavir in combination with ritonavir in HIV-1-infected patients. $\mathrm{Br} \mathrm{J} \mathrm{Clin}$ Pharmacol 2005, 60:378-389.

10. Jackson KA, Rosenbaum SE, Kerr BM, et al.: A population pharmacokinetic analysis of nelfinavir mesylate in human immunodeficiency virus-infected patients enrolled in a phase III clinical trial. Antimicrob Agents Chemother 2000, 44:1832-1837.

11. Pfister M, Labbé L, Lu JF, et al.: Effect of coadministration of nelfinavir, indinavir and saquinavir on the pharmacokinetics of amprenavir. Clin Pharmacol Ther 2002, 72:133-141.

12. Csajka C, Marzolini C, Fattinger K, et al.: Population pharmacokinetics and effects of efavirenz in patients with human immunodeficiency virus infection. Clin Pharmacol Ther 2003, 73:20-30.

13. Pfister M, Labbe L, Hammer SM, et al.: Population pharmacokinetics and pharmacodynamics of efavirenz, nelfinavir, and indinavir: Adult AIDS Clinical Trial Group Study 398. Antimicrob Agents Chemother 2003, 47:130-137.

A population pharmacokinetic and pharmacodynamic study that modeled the effect of covariates on its profile and evaluated the relationship between drug exposure and virologic failure with a particular focus on efavirenz.

14. Kappelhoff BS, van LF, MacGregor TR, et al.: Nevirapine and efavirenz pharmacokinetics and covariate analysis in the 2NN study. Antivir Ther 2005, 10:145-155.

15. Barrett JS, Joshi AS, Chai M, et al.: Population pharmacokinetic meta-analysis with efavirenz. Int J Clin Pharmacol Ther 2002, 40:507-519.

16. Burger D, van der Heiden I, la Porte C, et al.: Interpatient variability in the pharmacokinetics of the HIV non-nucleoside reverse transcriptase inhibitor efavirenz: the effect of gender, race, and CYP2B6 polymorphism. Br J Clin Pharmacol 2006, 61:148-154.

17. Lamba V, Lamba J, Yasuda K, et al.: Hepatic CYP2B6 expression: gender and ethnic differences and relationship to CYP2B6 genotype and CAR (constitutive androstane receptor) expression. J Pharmacol Exp Ther 2003, 307:906-922.

18. Sabo JP, Lamson MJ, Leitz G, et al.: Pharmacokinetics of nevirapine and lamivudine in patients with HIV-1 infection. AAPS PharmSci 2000, 2:E1.

19. De Maat MMR, Huitema ADR, Mulder JW, et al.: Population pharmacokinetics of nevirapine in an unselected cohort of HIV-1-infected individuals. Br J Clin Pharmacol 2002, 54:378-385.

20. Zhou XJ, Sheiner LB, D'Aquila RT, et al.: Population pharmacokinetics of nevirapine, zidovudine, and didanosine in human immunodeficiency virus-infected patients. The National Institute of Allergy and Infectious Diseases AIDS Clinical Trials Group Protocol 241 Investigators. Antimicrob Agents Chemother 1999, 43:121-128. 
21. Anderson PL, Kakuda TN, Kawle S, Fletcher CV: Antiviral dynamics and sex differences of zidovudine and lamivudine triphosphate concentrations in HIV-infected individuals. AIDS 2003, 17:2159-2168.

22. Jullien V, Treluyer JM, Rey E, et al.: Population pharmacokinetics of tenofovir in human immunodeficiency virus-infected patients taking highly active antiretroviral therapy. Antimicrob Agents Chemother 2005, 49:3361-3366.

23. Mould DR, Zhang X, Nieforth K, et al.: Population pharmacokinetics and exposure-response relationship of enfuvirtide in treatment-experienced human immunodeficiency virus type 1 -infected patients. Clin Pharmacol Ther 2005, 77:515-528.

24.• Wilson JF, Weale ME, Smith AC, et al.: Population genetic structure of variable drug response. Nat Genet 2001, 29:265-269.

A critical view and experimental data on the controversial issue of ethnicity as a phenotypic or genetic variable.

25. Kappelhoff BS, Huitema AD, Yalvac Z, et al.: Population pharmacokinetics of efavirenz in an unselected cohort of HIV-1-infected individuals. Clin Pharmacokinet 2005, 44:849-861.

26. Haas DW, Ribaudo HJ, Kim RB, et al.: Pharmacogenetics of efavirenz and central nervous system side effects: an Adult AIDS Clinical Trials Group study. AIDS 2004 , 18:2391-2400.

Genetic determinants of pharmacodynamics (toxicity) in the early phase of treatment.

27. Sadler BM, Gillotin C, Lou Y, Stein DS: In vivo effect of alpha(1)-acid glycoprotein on pharmacokinetics of amprenavir, a human immunodeficiency virus protease inhibitor. Antimicrob Agents Chemother 2001, 45:852-856.

28. Johnson JA, Livingston TN: Differences between blacks and whites in plasma protein binding of drugs. Eur J Clin Pharmacol 1997, 51:485-488.

29. Zhou HH, Adedoyin A, Wilkinson GR: Differences in plasma binding of drugs between Caucasians and Chinese subjects. Clin Pharmacol Ther 1990, 48:10-17.

30. Ioannidis JP, Ntzani EE, Trikalinos TA: "Racial” differences in genetic effects for complex diseases. Nat Genet 2004, 36:1312-1318.

31.• Fellay J, Marzolini C, Meaden ER, et al.: Response to antiretroviral treatment in HIV-1-infected individuals with allelic variants of the multidrug resistance transporter 1: a pharmacogenetics study. Lancet 2002, 359:30-36.

First comprehensive pharmacogenetics study in the field of antiretroviral therapy.

32.• Haas DW, Smeaton LM, Shafer RW, et al.: Pharmacogenetics of long-term responses to antiretroviral regimens containing efavirenz and/or nelfinavir: an Adult AIDS Clinical Trials Group Study. J Infect Dis 2005, 192:1931-1942.

Genetic determinants of pharmacodynamics (antiviral efficacy) in a clinical trial.

33. Frohlich M, Hoffmann MM, Burhenne J, et al.: Association of the CYP3A5 A6986G (CYP3A5*3) polymorphism with saquinavir pharmacokinetics. Br J Clin Pharmacol 2004, 58:443-444.

34. Mouly SJ, Matheny C, Paine MF, et al.: Variation in oral clearance of saquinavir is predicted by CYP3A $5 * 1$ genotype but not by enterocyte content of cytochrome P450 3A5. Clin Pharmacol Ther 2005, 78:605-618.

35. Eap CB, Buclin T, Cucchia G, et al.: Oral administration of a low dose of midazolam ( $75 \mathrm{microg}$ ) as an in vivo probe for CYP3A activity. Eur J Clin Pharmacol 2004, 60:237-246.

36. Wedlund PJ: The CYP2C19 enzyme polymorphism. Pharmacology 2000, 61:174-183.
37. Rodriguez-Novoa S, Barreiro P, Rendon A, et al.: Influence of $516 \mathrm{G}>\mathrm{T}$ polymorphisms at the gene encoding the CYP450-2B6 isoenzyme on efavirenz plasma concentrations in HIV-infected subjects. Clin Infect Dis 2005, 40:1358-1361.

38. Rotger M, Colombo S, Furrer H, et al.: Influence of CYP2B6 polymorphism on plasma and intracellular concentrations and toxicity of efavirenz and nevirapine in HIV-infected patients. Pharmacogenet Genomics $2005,15: 1-5$.

Genetic determinants of pharmacodynamics (toxicity) in the chronic phase of treatment.

39. Tsuchiya K, Gatanaga H, Tachikawa N, et al.: Homozygous CYP2B6 *6 (Q172H and K262R) correlates with high plasma efavirenz concentrations in HIV-1 patients treated with standard efavirenz-containing regimens. Biochem Biophys Res Commun 2004, 319:1322-1326.

First study showing the association between CYP2B6 516G>T and high efavirenz plasma levels.

40.• Klein K, Lang T, Saussele T, et al.: Genetic variability of CYP2B6 in populations of African and Asian origin: allele frequencies, novel functional variants, and possible implications for anti-HIV therapy with efavirenz. Pharmacogenet Genomics 2005, 15:861-873.

Comprehensive analysis of CYP2B6 diversity.

41. Wang J, Sonnerborg A, Rane A, et al.: Identification of a novel specific CYP2B6 allele in Africans causing impaired metabolism of the HIV drug efavirenz. Pharmacogenet Genomics 2006, 16:191-198.

42. Rotger M, Colombo S, Cavassini M, et al.: Genetic variability of CYP2B6 in individuals with extremely high efavirenz plasma concentrations [abstract]. Paper presented at the 13th Conference of Retroviruses and Opportunistic Infections. Denver, CO; February 5-8, 2006.

43. Hoffmeyer S, Burk O, von Richter O, et al.: Functional polymorphisms of the human multidrug-resistance gene: multiple sequence variations and correlation of one allele with P-glycoprotein expression and activity in vivo. Proc Natl Acad Sci U S A 2000, 97:3473-3478.

44. Wang D, Johnson AD, Papp AC, et al.: Multidrug resistance polypeptide 1 (MDR1, ABCB1) variant $3435 \mathrm{C}>\mathrm{T}$ affects mRNA stability. Pharmacogenet Genomics 2005, 15:693-704.

45. Schaeffeler E, Eichelbaum M, Brinkmann U, et al.: Frequency of C3435T polymorphism of MDR1 gene in African people. Lancet 2001, 358:383-384.

46. Colombo S, Soranzo N, Rotger M, et al.: Influence of ABCB1, ABCC1, ABCC2, and ABCG2 haplotypes on the cellular exposure of nelfinavir in vivo. Pharmacogenet Genomics 2005, 15:599-608.

Haplotypic analysis is not superior to single SNPs analysis for predicting nelfinavir intracellular levels.

47. Lee-Tauber B, Decosterd L, Kerb R, Telenti A: Pharmacogenetics in infectious. In Principles of Clinical Pharmacogenomics and Introduction to Pharmaco Proteomics. Edited by Wong SHY, Linder M, and Valdes R Jr. Abingdon: Taylor and Francis Books; 2006:155.

48. Saito S, Iida A, Sekine A, et al.: Identification of 779 genetic variations in eight genes encoding members of the ATP-binding cassette, subfamily C (ABCC/MRP/CFTR. J Hum Genet 2002, 47:147-171.

49. Chang TK, Bandiera SM, Chen J: Constitutive androstane receptor and pregnane $\mathrm{X}$ receptor gene expression in human liver: interindividual variability and correlation with CYP2B6 mRNA levels. Drug Metab Dispos 2003, 31:7-10.

50. Ikeda S, Kurose K, Ozawa S, et al.: Twenty-six novel single nucleotide polymorphisms and their frequencies of the NR1I3 (CAR) gene in a Japanese population. Drug Metab Pharmacokinet 2003, 18:413-418. 
51. Zhang J, Kuehl P, Green ED, et al.: The human pregnane $X$ receptor: genomic structure and identification and functional characterization of natural allelic variants. Pharmacogenetics 2001, 11:555-572.

52. Colombo S, Buclin T, Decosterd L, et al.: Orosomucoid plasma concentration and genetic variants: effects on HIV protease inhibitor clearance and cellular accumulation [abstract]. Paper presented at the 7 th International Workshop on Clinical Pharmacology of HIV Therapy. Lisbon; April 20-22, 2006.

53. Marzolini C, Kim RB, Telenti A: Pharmacogenetics of antiretroviral agnets. In AIDS Therapy. Edited by Dolin R, Masur H, and Saag MS. Oxford: Churchill Livingston; 2006.
54••. Haas DW, Wilkinson GR, Kuritzkes DR, et al.: A multiinvestigator/institutional DNA bank for AIDS-related human genetic studies: AACTG Protocol A5128. HIV Clin Trials 2003, 4:287-300.

A model initiative for integration of genetics in clinical research in drug trials.

55.• Chen DT, Rosenstein DL, Muthappan P, et al.: Research with stored biological samples: what do research participants want? Arch Intern Med 2005, 165:652-655.

A detailed description of the attitude of patients and healthy volunteers towards genetic research. Despite the common belief most participants are willing to provide permission to facilitate long-term use of their samples. 